\title{
Pertanggung Jawaban Hukum Terhadap Sitaan Yang Hidup Dalam Fungsi Rupbasan Sebagai Tempat Rumah Penyimpanan Benda Sitaan Negara
}

\begin{tabular}{|c|c|}
\hline \multicolumn{2}{|r|}{$\begin{array}{c}\text { Fero Frets Paren Wenur } \\
\text { Magister Hukum Universitas Indonesia }\end{array}$} \\
\hline Article Info & Abstract \\
\hline $\begin{array}{l}\text { Article history: } \\
\text { Received } 23 \text { November } 2021 \\
\text { Publish 01 Januari } 2022\end{array}$ & $\begin{array}{l}\text { In Article } 1 \text { point } 16 \text { of the Criminal Procedure Code, which reads "Confiscation is } \\
\text { a series of actions by an investigator to take over and or keep under his control } \\
\text { movable or immovable objects, tangible or intangible, for the purpose of proof in } \\
\text { investigation, prosecution., and the judiciary." confiscation is justified by law for } \\
\text { the purpose of criminal proceedings but must not be carried out arbitrarily but in }\end{array}$ \\
\hline $\begin{array}{l}\text { Keywords: } \\
\text { Sitaan Hidup, } \\
\text { Rupbasan,Hewan }\end{array}$ & $\begin{array}{l}\text { ways that have been determined or determined by law must not violate human } \\
\text { rights, so that in practice confiscation is still carried out with procedures and } \\
\text { basics. legal basis in law, although under Article } 39 \text { of the Criminal Procedure } \\
\text { Code, objects that can be subject to confiscation have been regulated in that article. } \\
\text { However, it only describes the confiscation of tangible or intangible movable goods } \\
\text { and immovable objects or goods which are used or obtained from criminal acts. So } \\
\text { it needs a comprehensive arrangement in managing the living confiscated objects. }\end{array}$ \\
\hline Info Artikel & Abstrak \\
\hline $\begin{array}{l}\text { Article history: } \\
\text { Diterima 23 November } 2021 \\
\text { Publis 01 Januari } 2022\end{array}$ & $\begin{array}{l}\text { Dalam Pasal } 1 \text { butir ke-16 Kitab Undang-Undang Hukum Acara Pidana, yang } \\
\text { berbunyi "Penyitaan adalah serangkaian tindakan penyidik untuk mengambil alih } \\
\text { dan atau menyimpan di bawah penguasaannya benda bergerak atau tidak bergerak, } \\
\text { berwujud atau tidak berwujud, untuk kepentingan pembuktian dalam penyidikan, } \\
\text { penuntutan, dan peradilan." penyitaan dibenarkan oleh undang-undang guna } \\
\text { kepentingan acara pidana namun tidak boleh dilakukan dengan semena-mena tetapi } \\
\text { dengan cara-cara yang telah ditetapkan atau ditentukan oleh undang-undang tidak } \\
\text { boleh melanggar hak asasi manusia, sehingga dalam perakteknya penyitaan tetaplah } \\
\text { dilakuan dengan prosedur dan dasar-dasar yang sah dalam hukum, meski demkian } \\
\text { Berdasarkan Pasal } 39 \text { KUHAP benda-benda yang dapat dikenakan Penyitaan telah } \\
\text { di atur dalam pasal tersebut. Akan tetapi Hanya menjabarkan perampasan terhadap } \\
\text { barang bergerak yang berwujud atau tidak berwujud serta benda atau barang yang } \\
\text { tidak bergerak dimana yang digunakan atau yang di peroleh dari tindak pidana. } \\
\text { Sehingga perlu pengaturan yang komprehensif dalam mengatur objek sitaan yang } \\
\text { hidup. }\end{array}$ \\
\hline
\end{tabular}

This is an open access article under the Lisensi Creative Commons AtribusiBerbagiSerupa 4.0 Internasional

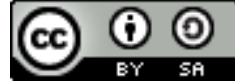

Corresponding Author:

Fero Frets Paren Wenur

Magister Hukum, Universitas Indonesia

Email: fero.frets.paren.w20@gmail.com

\section{PENDAHULUAN}

Menurut Hans Kelsen, tanggung jawab berkaitan erat dengan kewajiban, namun tidak identik. Kewajiban tersebut muncul karena adanya aturan hukum yang mengatur dan memberikan kewajiban kepada subyek hukum. Subyek hukum yang dibebani kewajiban harus melaksanakan kewajiban tersebut sebagai perintah dari aturan hukum

Dalam Pasal 1 butir ke-16 Kitab Undang-Undang Hukum Acara Pidana, yang berbunyi "Penyitaan adalah serangkaian tindakan penyidik untuk mengambil alih dan atau menyimpan di 
bawah penguasaannya benda bergerak atau tidak bergerak, berwujud atau tidak berwujud, untuk kepentingan pembuktian dalam penyidikan, penuntutan, dan peradilan."

Penyitaan dibenarkan oleh undang-undang guna kepentingan acara pidana namun tidak boleh dilakukan dengan semena-mena tetapi dengan cara-cara yang telah ditetapkan atau ditentukan oleh undang-undang tidak boleh melanggar hak asasi manusia, sehingga dalam perakteknya penyitaan tetaplah dilakuan dengan prosedur dan dasar-dasar yang sah dalam hukum, meski demkian Berdasarkan Pasal 39 KUHAP benda-benda yang dapat dikenakan Penyitaan telah di atur dalam pasal tersebut.

Berdasarkan Pasal 39 KUHAP benda-benda yang dapat dikenakan Penyitaan ;

(1) Yang Dapat Dikenakan Penyitaan Adalah:

a)Benda atau tagihan tersangka atau terdakwa yang seluruh atau sebagai diduga diperoleh dari tindak pidana atau sebagian hasil dari tindak pidana;

b) Benda yang telah dipergunakan secara langsung untuk melakukan tindak pidana atau untuk mempersiapkannya;

c)Benda yang dipergunakan untuk menghalang-halangi penyelidikan tindak pidana;

d) Benda yang khusus dibuat atau diperuntukkan melakukan tindak pidana;

e)Benda lain yang mempunyai hubungan langsung dengan tindak pidana yang dilakukan

Melalui perampasan terhadap barang itu sendiri dimana barang dalam pengertian secara umum menurut undang-undang di definisikan sebagai barang adalah tiap benda dan tiap hak yang dapat menjadi objek dari hak milik termuat dalam pasal 499 Kitab Undang-Undang Hukum Perdata, sesuai dengan pernyataan tersebut adala hak milik dari si pelaku.

Akan tetapi Benda sitaan yang diperoleh karena adanya perkara pidana, telah menimbulkan permasalahan yang rumit karena di samping pentingnya sebagai bukti dalam proses pengadilan, juga karena nilainya yang sangat berharga, baik nilainya bagi perkara, maupun nilai nominalnya, khususnya dalam perkara besar seperti korupsi. Dan oleh sebab itu banyak mempengaruhi tentunya perhatian dan kebutuhan terhadap peroses penyitaan, terhadap benda atau barang yang ada.

Hanya menjabarkan perampasan terhadap barang bergerak yang berwujud atau tidak berwujud serta benda atau barang yang tidak bergerak dimana yang digunakan atau yang di peroleh dari tindak pidana. Sehingga menjadikan keterbatasan dalam menindak suatu perbuatan pidana yang dimana seharusnya berlandaskan asas legalitas.

Adapun dalam proses penyitaan yang dilakukan oleh penyidik yang berwenang yang di tunjuk oleh Undang-Undang. Dalam Kitab Undang-Undang Hukum Acara Pidana, Pada pasal 39 secara formil mengatur dalam definisi barang atau benda yang dapat dikenakan penyitaan setelahnya sesuai dengan Pasal 44 Kuhap akan di akan di simpan dalam rumah penyimpana benda sitaan negara. Sementara dalam perakteknya sejauh ini sudah banyak hewan yang menjadi objek sitaan Pada kenyataan yang terjadi hewan-hewan tersebut di taruh di balai konservasi dan sejenis nya ada beberapa hewan sitaan yang terancam mati akibat kekurangan makanan serta perawatan yang kurang memadai akibat dari keterbatasan sarana dan prasarana yang ada, serta hewan-hewan yang di terima tidak selalu dalam keadaan yang baik-baik saja ada yang stres serta mengalami sakit akibat perlakuan atau perawataan yang kurang baik dari si pemiliknya sehingga perlunya perhatian dan penanganan yang serius dari penegak hukum. Tidak hanya dari proses kebutuhan hukum nya saja yang perlu perhatian khusus, akan tetapi dari hewan yang merupakan hasil sitaan tersebut juga harus di lindungi dan harus ada tanggung jawab secara pengaturan hukum yang mengatur dan sikap tindak yang sesuai dengan kebutuhan hewan-hewan tersebut.

\section{METODE PENELITIAN}

Jenis penelitian hukum yang dilakukan secara yuridis normatif adalah yuridis normatif dimana hukum dikonsepkan sebagai apa yang tertulis dalam peraturan perundang-undangan (law in books) atau hukum dikonsepkan sebagai kaidah atau norma yang merupakan patokan berperilaku manusia 
yang dianggap pantas. Penelitian hukum normatif ini diadasrakan kepada bahan hukum primer dan sekunder, yaitu penelitian yang mengacu kepada norma-norma yang terdapat dalam peraturan perundang-undanganDengan singkatnya bahwa penelitian yuridis normatif membahas doktridoktrin atau asas-asas dalam ilmu hukum.

Dalam penelitian ini, ruang lingkup penelitian ini akan dilakukan penelitian dengan cara menarik asas hukum, dimana dilakukan terhadap hukum positif tertulis maupun tidak tertulis. Penelitian ini dapat digunakan untuk menarik asas-asas hukum dalam menafsirkan peraturan peundang-undangan. Selain itu, penelitian ini juga, dapat digunakan untuk mencari asas hukum yang dirumuskan baik secara tersirat maupun tersurat.

\section{HASIL PENELITIAN DAN PEMBAHASAN}

Dalam Pasal 1 butir ke-16 Kitab Undang-Undang Hukum Acara Pidana, yang berbunyi "Penyitaan adalah serangkaian tindakan penyidik untuk mengambil alih dan atau menyimpan di bawah penguasaannya benda bergerak atau tidak bergerak, berwujud atau tidak berwujud, untuk kepentingan pembuktian dalam penyidikan, penuntutan, dan peradilan."

Penyitaan yang terdapat dalam Pasal 1 butir 16 KUHAP diatas adalah tindakan penyidik dalam melakukan pengambil alihan maupun penyimpanan benda-benda milik seorang merupakan bagian dari upaya paksa. Tindakan penyidik tersebut dibenarkan oleh hukum sepanjang sesuai dengan ketentuan peraturan perundang-undangan.

Melalui perampasan terhadap barang itu sendiri dimana barang dalam pengertian secara umum menurut undang-undang di definisikan sebagai barang adalah tiap benda dan tiap hak yang dapat menjadi objek dari hak milik termuat dalam pasal 499 Kitab Undang-Undang Hukum Perdata, sesuai dengan pernyataan tersebut adala ha milik dari si pelaku.

Berdasarkan Pasal 39 KUHAP benda-benda yang dapat dikenakan Penyitaan ;

(1) Yang Dapat Dikenakan Penyitaan Adalah:

a)Benda atau tagihan tersangka atau terdakwa yang seluruh atau sebagai diduga diperoleh dari tindak pidana atau sebagian hasil dari tindak pidana;

b) Benda yang telah dipergunakan secara langsung untuk melakukan tindak pidana atau untuk mempersiapkannya;

c)Benda yang dipergunakan untuk menghalang-halangi penyelidikan tindak pidana;

d) Benda yang khusus dibuat atau diperuntukkan melakukan tindak pidana;

e)Benda lain yang mempunyai hubungan langsung dengan tindak pidana yang dilakukan

Dalam perjalanannya dapat kita lihat bahwa terhadap beda-benda atau barang-barang yang menjadi perhatian dari pada aturan yang ada meski jika kita melihat di lapangan bahwa tidak semua yang menjadi objek sitaan adalah benda-benda atau barang-barang yang dimana itu adalah benda mati akan tetapi dapat kita jumpai di lapangan bahwa tumbuhan dan hewan juga menjadi objek sitaan yang hidp dan banyak di jumpai saat ini.

\subsection{Pengaturan keberadaan sitaan terhadap hewan kepada Rupbasan}

Barang Sitaan atau Benda Sitaan sebagai Pidana Tambahan (menurut Pasal 10 KUHP) Jan Remmelink berpendapat bahwa benda sitaan mempunyai lingkup yang terbatas yakni hanya menyangkut pada harta benda atau kekayaan (vermogenstraaf) . Bahkan dalam Straftrecht (Sr) turut diatur dalam Pasal 33 bahwa benda yang dapat disita diantaranya mencakup :

a. benda yang dimiliki oleh terpidana secara keseluruhan maupun sebagian yang dipergunakan sendiri atau diperolehnya dari perbuatan kejahatan;

b.benda yang dipergunakan untuk kejahatan;

c. benda dengan bantuan untuk perbuatan kejahatan;

d.benda dengan bantuan untuk menghalangi penyidikan;

e. benda yang akan digunakan untuk perbuatan kejahatan; dan 
f. hak atas kebendaan. Seperti yang di atas telah di jabarkan benda atau barang yang dapat disita dan dalam hal tersebut terhadap dilihat binatang yang sebagai mahluk hidup tidak menjadi kajian dalam aturannya.

Adapun seperti yang menjadi kajian dalam pembahasan di atas bahwa hanya meliputi benda sitaan dan barang sitaan saja yang dimana itu tergolong sebagai harta benda atau kekayaan sementara di sisilain dapat kita lihat bahwa terhadap binatang atau hewan yang diaman itu adalah mahluk hidup tidak menjadi kajiannya.

Kemudian adapun kriteria untuk benda-benda yang dapat dilakukan penyitaan, sebagaimana diatur dalam Pasal 39 ayat (1) KUHAP yaitu:

a)Benda atau tagihan tersangka atau terdakwa yang seluruh atau sebagian diduga diperoleh dari tindak pidana atau sebagai hasil dari tindak pidana;

b) Benda yang telah dipergunakan secara langsung untuk melakukan tindak pidana atau untuk mempersiapkan;

c)Benda yang dipergunakan untuk menghalang-halangi penyidikan tindak pidana;

d) Benda yang khusus dibuat atau diperuntukan melakukan tindak pidana;

e)benda lain yang mempunyai hubungan langsung dengan tindak pidana yang dilakuka

Serta dalam pasal 39 Kuhap sendiri juga sepenuhnya membahas terkait sitaan dalam lingkupan barang atau benda saja sedangkan dalam kenyataanya tida hanya barang yang menjadi objek dari penyitaan dimana dapat kita temui mahluk hidup seperti tanaman dan juga hewan yang juga menjadi objek dari sitaan hidup sehingga disini dapat kita patikan dalam pengelolaan terhadap hewan-hewan tersebut juga tidak memiliki pengaman yang tepat.

Adapun dalam proses penyitaan yang dilakukan oleh penyidik yang berwenang yang di tunjuk oleh Undang-Undang. Dalam Kitab Undang-Undang Hukum Acara Pidana, Pada pasal 39 secara formil mengatur dalam definisi barang atau benda yang dapat dikenakan penyitaan Dan setelah benda atau barang tersebut disita akan di simpan dalam rumah penyimpana benda sitaan negara.

Pada kenyataan yang terjadi hewan-hewan tersebut di taruh di balai konservasi dan sejenis nya ada beberapa hewan sitaan yang terancam mati akibat kekurangan pangan serta perawatan yang kurang memadai akibat dari keterbatasan sarana dan prasarana yang ada, serta hewanhewan yang di terima tidak selalu dalam keadaan yang baik-baik saja ada yang stres serta mengalami sakit akibat perlakuan atau perawataan yang kurang baik dari si pemiliknya sehingga perlunya perhatian dan penanganan yang serius dari penegak hukum.

Tidak hanya dari proses kebutuhan hukum nya saja yang perlu perhatian khusus, akan tetapi dari hewan yang merupakan hasil dari tindak pidana juga harus di pertanggung jawabkan baik dari Proses penangkapan yang harus hati-hati akan tetapi juga dari peroses perawatan dan serta perlindungan terhadap nyawa hewan tersebut

Sehingga pada prinsipnya perlunya regulasi untuk mengatur bagi sitaan hidup tersebut baik dalam cakupan Materil Maupun Formil, adapun sitaan hidup tersebut adalah hewan atau binatang dimana dalam prinsipnya berbeda dengan barang yang adalah benda mati, sehingga perlu perawatan yang berbeda dan tidak boleh stres dapat sakit jika tidak dalam perawatan yang tepat sehingga dapat menyebapkan kematian. Pada perinsipnya negara bertanggung jawab melindungi dan memberi perlindungan dan perawatan bagi hewan Sitaan.

\subsection{Pertanggung jawaban Rupbasan terhadap hewan tersebut}

Jadi Rupbasan adalah tempat benda yang disita oleh Negara untuk keperluan proses peradilan. Rupbasan didirikan pada setiap ibukota kabupaten atau kota, dan apabila perlu dapat dibentuk pula cabang Rupbasan. Di dalam Rupbasan ditempatkan benda yang harus disimpan untuk keperluan barang bukti dalam pemeriksaan dalam tingkat penyidikan, penuntutan dan pemeriksaan di sidang pengadilan termasuk barang yang dinyatakan dirampas berdasarkan putusan hakim 
Dalam Pasal 44 dinyatakan bahwa;

(1) Benda sitaan disimpan dalam rumah penyimpanan benda sitaan negara.

(2) Penyimpanan benda sitaan dilaksanakan dengan sebaik-baiknya dan tanggung jawab atasnya ada pada pejabat yang berwenang sesuai dengan tingkat pemeriksaan dalam proses peradilan dan benda tersebut dilarang untuk dipergunakan oleh siapapun juga.

Dalam Peraturan Menteri Kehakiman RI No. M.05.UM.01.06 Tahun 1983 tentang Pengelolaan Benda Sitaan Negara dan Barang Rampasan Negara di Rumah Penyimpanan Benda Sitaan, memberi pengertian benda sitaan dan barang rampasan, yaitu:

1. Benda Sitaan/Benda Sitaan Negara (disingkat Basan) adalah benda yang disita oleh penyidik, penuntut umum atau pejabat yang karena jabatannya mempunyai wewenang untuk menyita barang guna keperluan barang bukti dalam proses peradilan.

2. Barang Rampasan/Barang Rampasan Negara (disingkat baran) adalah barang bukti yang telah memperoleh kekuatan hukum tetap, dirampas untuk Negara yang selanjutnya dieksekusi dengan cara:

a. dimusnahkan;

b. dilelang untuk negara;

c. diserahkan kepada instansi yang ditetapkan untuk dimanfaatkan; dan

d. diserahkan di Rumah Penyimpanan Benda Sitaan (RUPBASAN) untuk barang bukti dalam perkara lain.

Bertitik tolak dari ketentuan pasal 44 ayat (1) UU RI Nomor 8 Tahun 1981 tentang KUHAP yang menyatakan bahwa benda sitaan disimpan dalam rumah barang benda sitaan negara. yang selanjutnya dalam ketentuan Pasal 27 ayat (1) PP RI Nomor 27 tahun 1983 tentang pelaksanaan Kitab Undang - Undang Hukum Acara Pidana disebutkan dalam RUPBASAN ditempatkan benda yang harus disimpan untuk keperluan barang bukti dalam pemeriksaan dalam tingkat penyidikan, penuntutan, dan pemeriksaan di sidang pengadilan termasuk barang yang dinyatakan dirampas berdasarkan putusan hakim, maka terkandung pengertian bahwa :

a. Setiap barang sitaan oleh negara untuk keperluan proses peradilan harus disimpan di

RUPBASAN.

b.RUPBASAN adalah satu - satunya tempat penyimpanan benda sitaan oeh negara, termasuk barang yang dirampas berdasarkan putusan hakim.

c. Dari fungsi kelembagaan RUPBASAN merupakan pusat penyimpanan benda sitaan dan barang rampasan negara dari seluruh instansi yang melakukan penyitaan hasil tindak pidana. d.Dalam hal benda sitaan tersebut tidak mungkin dapat disimpan dalam RUPBASAN, maka cara penyimpanan benda sitaan tersebut diserahkan kepada Kepala RUPBASAN (Pasal 27 ayat (2) PP No. 27 Tahun 1983).

Terhadap hal-hal yang termuat di atas dimana terhadapa hal-hal yang menjadi objek sitaan yang dimana tidak dapat di simpan dalam Rupbasan, maka terhadap objek tersebut akan di serahkan pada kepala Rupbasan yang dimana telah di atur dalam Pasal 27 ayat (2) PP No. 27 Tahun 1983

PP No.27 Tahun 1983 Tentang Pelaksanaan Kitab Undang-Undang Hukum Acara pidana dalam ayat (2) dimana dalam, hal benda sitaan sebagaimana dimaksud dalam ayat (1) tidak mungin dapat di simpan dalam Rupbasan, maka cara penyimpanan benda sitaan tersebut diserahkan kepada kepala Rupbasan.

Akan tetapi dalam perakteknya, terhadap hewan sitaan tidak memiliki mekanisme penanganan yang dimana dalam pengaturan Rupbasan yang mencakup pemeliharaan dan pengelolaan terhadap objek sitaan tidak mencakup terhadap sitaan yang beradaa di luar Rupbasan, sedangkan hewan sitaan masih masuk dalam objek sitaan akan tetapi dalam penanganan yang terjadi dan pemeliharaan terhadap sitaan hidup tersebut berada di luar Rupbasan sehingga tidak ada pengaturan dan penanganan yang pasti dalam mengelola sitaan 
yang hidup sehingga dapat di pastikan terhadap hewan sitaan yang hidup memiliki kerentanan yang tinggi akan kematian yang akibat dari penanganan dan pengelolaan yang tidak di atur,

\section{KESIMPULAN}

Dari hasil penelitian dapat penulis simpulkan bahwa:

4.1 Penyitaan yang dilakukan terhadap hewan atau binatang dalam memenuhi kewajiban hukum seperti yang di lakukan atas benda sitaan dan atau barang dimana seperti yang di atur dalam Pasal 39 Kuhap masih belum memberikan kepastian dalam penyitaan terhadap hewan dimana dalam pasal tersebut hanya mengatur dalam kontek barang atau benda yang tergolong sebagai sebagai benda mati akan tetapi berbeda dengan sitaan yang hidup seperti binatang dalam penanganan dan perlakukan nya seharusnya berbeda seperti pada saat dilakukannya proses penyitaan yang seharusnya memiliki standar yang di kuasai oleh penyidik dalam membawa dan menggambil hewan-hewan tersebut belum lagi terhadap hewan yang dimana banyak di jumpai pada saat dilakuan nya penyitaan seharusnya di tangani dengan perlengkapan yang memadai mengingat mereka adalah mahluk hidup. Selanjutnya Pada kenyataan yang terjadi hewanhewan tersebut di taruh di balai konservasi dan sejenis nya ada beberapa hewan sitaan yang terancam mati akibat kekurangan makanan serta perawatan yang kurang memadai akibat dari keterbatasan sarana dan prasarana yang ada, serta hewan-hewan yang di terima tidak selalu dalam keadaan yang baik-baik saja ada yang stres serta mengalami sakit akibat perlakuan atau perawataan yang kurang baik dari si pemiliknya sehingga perlunya perhatian dan penanganan yang serius dari penegak hukum. Tidak hanya dari proses kebutuhan hukum nya saja yang perlu perhatian khusus, terhadap hewan yang merupakan hasil sitaan tersebu.

4.2 Peran Rupbasan dalam pengelolaan terhadap sitaan Negara Rupbasan terhadap sitaan yang hidup belum dapat terlaksanakan dengan jelas mengingat bahwa sitaan yang hidup dalam pengaturan nya belum secara jelas di aturan dalam pengaturan yang ada seperti dalam Kuhap dan dalam pengaturan khusus yang memuat fungsi Rupbasan sehingga perlunya pengaturan yang jelas dalam regulasi yang akan datang seperti yang termuat dalam Kuhap dan peran dan fungsi Rupbasan dalam mengklasifikasikan Barang dan Benda, mengingat bahwa dalam peran dan fungsi Rupbasan sangat jelas mengatur peran dan fungsi Rupbasan, jika kita melihat bahwa saat ini banyak hewan yang yang menjadi objek sitaan berada di Balai Konservasi Sumber Daya Alam (BKSDA), dimana dalam penanganan yang ada tidak di atur dalam Rupbasan sehingga perlunya pengaturan terhadap sitaan yang hidup, agar mendapat kejelasan dalam pengatura dan pemeliharaannya sehingga dapat menghindari dan mengurangi akibat dari banyaknya sitaan yang hidup, mati akibat penanganan dan pengelolaan sitaan yang tidak sesuai prosedur.

\section{UCAPAN TERIMAKASIH}

Puji syukur kepada Tuhan yang Maha Esa.karena atas berkat dan Anugrah-Nya, sehingga penulis mampu dan berhasil menyelesaikan Tulisan ini yang berjudul "PERTANGGUNG JAWABAN HUKUM TERHADAP SITAAN YANG HIDUP DALAM FUNGSI RUPBASAN SEBAGAI TEMPAT RUMAH PENYIMPANAN BENDA SITAAN NEGARA".Sebagai manusia biasa, tentu sangat sadar bahwa Tulisan ini tidak akan bisa terselesaikan tanpa dukungan dan bantuan banyak pihak baik secara langsung maupun tidak langsung. Oleh karena itu penulis mengucapkan terima kasih dan penghargaan setinggi-tingginya kepada Setiap orang yang boleh terlibat dalam mendukung penulis hingga dapat menyelesaikan Jurnal ini, penulis mengucapkan Terimakasih.

\section{DAFTAR PUSTAKA}

Apeldoorn Van L.j dalam Shidarta,Moralitas Profesi Hukum Suatu Tawaran Kerangka Berfikir, PT.REVIKA Aditama,Bandung,2006, 
Asshiddiqie Jimly dan Ali Safa'at, Teori Hans Kelsen Tentang Hukum, Cet.1. (Jakarta: Sekretariat Jenderal \& Kepaniteraan Mahkamah Konstitusi RI, 2006)

Hamzah Andi, Hukum Acara Pidana Indonesia, Cet. 7, (Jakarta: Sinar Grafika, 2013).

Harahap Yahya, Pembahasan, Permasalahan dan Penerapan KUHAP, Sinar Grafika, Jakarta, 2012.

Ibrahim Johnny, Teol \& Metodologi penelitian hukum normatif, 2012, bayumedia publishing, malang.

Johan, Bahder Nasution, Metode Penelitian Ilmu Hukum, Nandar Maju, Bandung, 2008.

Kansil C.S.T. dan Christine S.T Kansil, 2004, Pokok-Pokok Hukum Pidana, Pradnya Paramita, Jakarta.

Kansil Cst, Kamus istilah Hukum, Gramedia Pustaka, Jakarta, 2009.

Karang Agustina Kadek, Animal Welfare, (Fakultas Kedokteran Hewan Universitas Udayana, 2017).

Lubis Hidayat Daud, "Pertanggungjawaban Pidana Anak Menurut Hukum Pidana Positif Dan Hukum Pidana Islam"

Marlang Abdullah dan Rina Maryana, Hukum Konservasi Sumber Daya Alam Ekosistemnya, (Jakarta: Mitra Wacana Media, 2015).

Hayati dan 